Doris Kloor $\cdot$ Ksenija Fumic $\cdot$ Sebastian Attig

Martina Tete $\cdot$ Hartmut Osswald · Ivo Baric

Jürgen Tomiuk · Jost Kömpf

\title{
Studies of S-adenosylhomocysteine-hydrolase polymorphism in a Croatian population
}

Received: 1 July 2005/ Accepted: 6 September 2005 / Published online: 5 November 2005

(C) The Japan Society of Human Genetics and Springer-Verlag 2005

\begin{abstract}
Recently, a proven case of human S-adenosylhomocysteine-hydrolase (SAHH) deficiency was reported in a Croatian boy. As molecular analysis of the SAHH gene in this case revealed two different mutant alleles, we investigated the polymorphism of human SAHH in a total of 237 red blood samples from unrelated Croats using starch gel electrophoresis and an enzyme-specific staining procedure. From the relative enzymatic activity of SAHH - determined by densitometric assessment of electrophoretic patterns, and calculated on the basis of the protein concentration of the red blood cells - we detected three individuals as being heterozygous for an SAHH 0-allele. Moreover, a total of four different electromorphic SAHHs have been observed, giving allele frequencies calculated as SAHH $1=0.941$, SAHH $2=0.032$, SAHH $3=0.006$, SAHH $4=0.015$, and SAHH $0=0.006$.
\end{abstract}

Keywords S-Adenosylhomocysteine-hydrolase · Polymorphism $\cdot$ Allele frequencies

D. Kloor $(\bowtie) \cdot$ M. Tete $\cdot$ H. Osswald

Department of Pharmacology and Toxicology,

Faculty of Medicine, University of Tübingen,

Wilhelmstraße 56, 72074 Tübingen, Germany

E-mail: doris.kloor@uni-tuebingen.de

Tel.: +49-7071-2974941

Fax: + 49-7071-294942

K. Fumic

Clinical Institute of Laboratory Diagnosis,

University Hospital Centre, Zagreb, Croatia

I. Baric

Department of Pediatrics, University Hospital Centre,

Zagreb, Croatia

S. Attig $\cdot$ J. Tomiuk $\cdot$ J. Kömpf

Institute of Human Genetics, Faculty of Medicine,

University of Tübingen, Wilhelmstraße 27,

72074 Tübingen, Germany

\section{Introduction}

S-Adenosylhomocysteine-hydrolase (SAHH, EC 3.3.1.1) catalyses the reversible hydrolysis of S-adenosylhomocysteine (SAH) to adenosine and homocysteine (De la Haba and Cantoni 1959). SAH is a product and inhibitor of all S-adenosylmethionedependent transmethylation reactions (Ueland 1982; Clarke and Banfield 2001). Therefore, rapid and efficient removal of SAH is necessary to maintain SAH tissue content at a low level (Cantoni and Chiang 1980). Thus, physiologically, SAHH not only serves to sustain the flux of methionine sulphur toward cysteine, but is also an essential enzyme playing a key role in the regulation of biological methylation (Cantoni and Chiang 1980; Hermes et al. 2004). In vertebrates, SAHH is the only enzyme known to hydrolyse the $\mathrm{SAH}$ formed, and deletion of the SAHH gene is associated with embryo lethality in mice (Miller et al. 1994). A recent study reported a proven human case of inherited SAHH deficiency in a Croatian patient (Baric et al. 2004). Since molecular analysis of the SAHH gene in this latter case revealed two different mutations, it is of particular interest to determine the incidence of SAHH 0-alleles in the Croatian population.

Human red blood cell SAHH exhibits genetic polymorphism. The electromorphic patterns are determined by three autosomal codominant alleles-SAHH 1, SAHH 2, and SAHH 3. The gene frequencies of SAHH 1 and SAHH 2 in European samples (Germany: Bissbort et al. 1983; Italy: Corbo et al. 1987) have been estimated as 0.97 and 0.025 , respectively. The frequencies for these alleles differ in a Japanese population-estimated at 0.95 and 0.047 , respectively (Katsunori et al. 1984).

In this study, we present data on the distribution of SAHH phenotypes and gene frequencies in a Croatian population. 


\section{Materials and methods}

Fresh blood samples collected in EDTA solution were randomly taken from hospital laboratory from 237 unrelated Croats in Zagreb. The red blood cell sediments were washed twice in saline, stored at $-20^{\circ} \mathrm{C}$, and were shipped on dry ice to the Department of Pharmacology and Toxicology, University of Tübingen, Germany. Red cell lysates were prepared by ultrasonic disintegration and toluene treatment (three parts red cells, one part toluene). For starch gel electrophoresis (SGE), haemolysates were prepared according to the method of Rocha et al. (1988). Briefly, pretreatment was achieved by mixing 10 volumes haemolysate and 1 volume $65 \mathrm{mmol} / 1$ dithiothreitol. From each sample, $50 \mu$ haemolysate was applied to the gel. The minimum amount of protein necessary for detection of SAHH activity is $10 \mathrm{mg}$.

Horizontal SGE was carried out in a Tris-histidine (His) $/ \mathrm{HCl}$ buffer system, pH 7.4, at $7 \mathrm{~V} / \mathrm{cm}$ for $16 \mathrm{~h}$ with cooling $\left(4^{\circ} \mathrm{C}\right)$. The bridge buffer used was $0.2 \mathrm{~mol} / 1$ Tris and $0.17 \mathrm{~mol} / 1 \mathrm{His} \times \mathrm{HCl}$. The gel buffer was a $1: 7$ dilution of the bridge buffer.

The staining procedure was performed using a cellulose acetate membrane overlay. The staining solution contains potassium phosphate buffer $\mathrm{pH}$ 7.0, SAH $(4.3 \mathrm{mmol} / \mathrm{l})$, MTT $(5 \mathrm{mmol} / \mathrm{l})$, meldolablue $(55 \mu \mathrm{mol} / \mathrm{l})$, $8 \mathrm{U}$ adenosine deaminase, $2 \mathrm{U}$ nucleoside phosphorylase, and $1 \mathrm{U}$ xanthine oxidase. The gel slices were incubated at $37^{\circ} \mathrm{C}$ for $1 \mathrm{~h}$. Following this incubation period, the cellulose acetate membrane was rinsed in water and immediately scanned.

The electrophoretic patterns were assessed densitometrically using the computer program TINA (version 2.09a).

The protein concentration of the haemolysates was determined according to the method described by Bradford (1976) using bovine serum albumin as a standard.

\section{Calculation and statistics}

Allele frequencies were estimated by gene counting from electrophoretic patterns. The observed genotype distribution of populations was compared statistically with the expected Hardy-Weinberg proportions using the exact Fisher's test with the program GENEPOP (version 3.1d) (Raymond and Rousset 1995). Deviation from Hardy-Weinberg equilibrium was considered significant when the type I error $P$ was larger than the assumed significance level $\alpha=0.05$.

SAHH activity was expressed as a ratio of the densitometric density and the protein content of the corresponding sample. The distribution of activities in the sample is compatible with the hypothesis of a standardised normal distribution. Values were accepted as significantly low if (1) $P<P_{\mathrm{z}}(\alpha$ one-sided $=0.05)$, and (2) the corresponding protein content was not outside the significance level $P_{\mathrm{z}}(\alpha=0.05)$. Activities were interpreted genetically as heterozygous for the silent allele $\mathrm{SAHH} 0$ if their ratios were $\leq 50 \%$ of the standard mean.

\section{Results and discussion}

S-Adenosylhomocysteine-hydrolase polymorphism was studied in 237 red blood samples from unrelated Croatians. Figure 1 presents the electrophoretic patterns observed, and Table 1 reports the distribution of SAHH genotypes and gene frequencies. The protein concentrations of the haemolysates used in this study were between 207.3 and $433.1 \mathrm{mg} / \mathrm{ml}$. The mean values of protein concentrations of the haemolysates $(310 \pm 3.0 \mathrm{mg} / \mathrm{ml})$ do not differ significantly between the different phenotypes (data were analysed by ANOVA and Turkey-Kramer test for multiple comparison). The observed number of genotypes corresponded with that expected on the assumption of a Hardy-Weinberg equilibrium $(P=0.1283>\alpha=0.05)$. Genotypic comparisons between the Croatian sample and a German population at six protein loci (SAHH, adenosine deaminase, alanine aminotransferase, esterase D, 1-antitrypsin; unpublished data) revealed no significant difference also for the SAHH locus $(P=0.530)$.

In the Croatian population, the slowly moving variant, SAHH 3 shows the same gene frequency as in a German population (Scheil and Borner 1985). Furthermore, we detected a new variant type, SAHH 4, in the

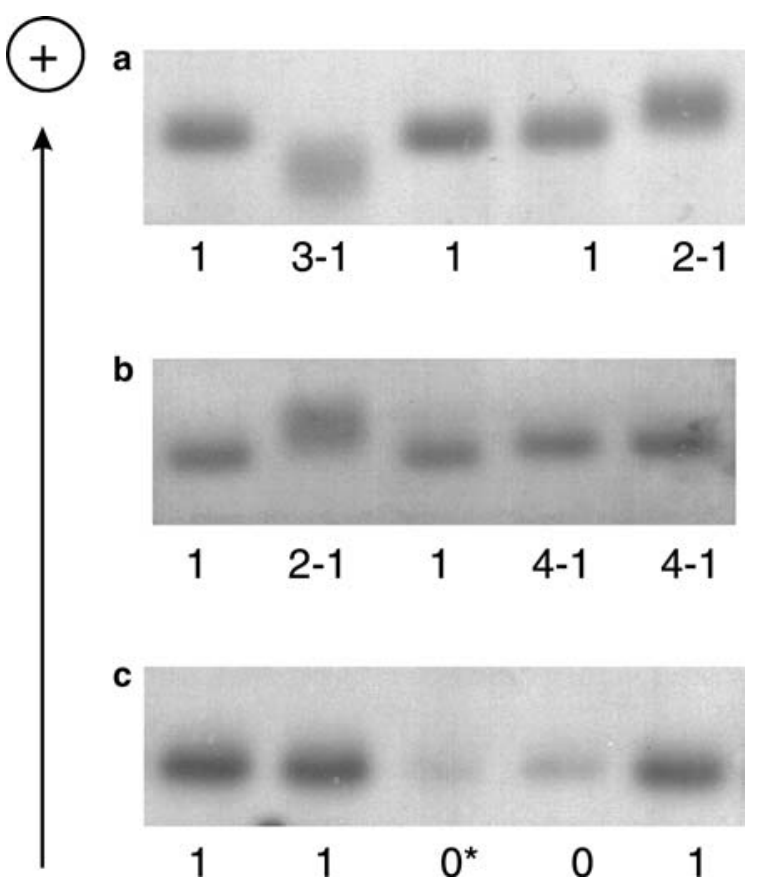

Fig. 1 a-c Zymograms of electrophoretic patterns showing common and rare S-adenosylhomocysteine-hydrolase (SAHH) phenotypes by starch gel electrophoresis (SGE) 
Table 1 S-Adenosylhomocysteine-hydrolase (SAHH) genotypes and gene frequencies among unrelated Croatian blood donors. Expected number of genotypes and gene frequencies were calculated according to exact Fisher's test using the program GENEPOP (version 3.2d); for the computation of the expected number of genotypes, Levene's corrections was used. Observed and expected number of genotypes do not differ significantly $(P=0.1283$; $>\alpha=0.05)$

\begin{tabular}{|c|c|c|c|c|c|c|c|c|}
\hline & \multicolumn{8}{|l|}{ Genotypes } \\
\hline & $1-1$ & $2-1$ & $3-1$ & $4-1$ & $0-1$ & $0-3$ & Others & Total \\
\hline \multirow{5}{*}{$\begin{array}{l}\text { Observed number } \\
\text { Expected number }\end{array}$} & 210 & 15 & 2 & 7 & 2 & 1 & 0 & 237 \\
\hline & 209.80 & 14.14 & 2.83 & 6.60 & 2.83 & 0.02 & 0.78 & 237 \\
\hline & \multicolumn{8}{|c|}{ Gene frequencies } \\
\hline & SAHH*1 & $\mathrm{SAHH}^{*} 2$ & & $\mathrm{SAHH}^{*} 3$ & $\mathrm{SAHH}^{*} 4$ & \multicolumn{2}{|c|}{$\mathrm{SAHH}^{*} 0$} & \\
\hline & 0.941 & 0.032 & & 0.006 & 0.015 & \multicolumn{2}{|c|}{0.006} & \\
\hline
\end{tabular}

Croatian samples (Fig. 1b). Since it is known that the red blood cell SAHH 1 molecule can undergo an electrophoretic shift to the anode from at least one free $\mathrm{SH}-$ group (Corbo et al. 1987; Scozzari et al. 1987), the red cell lysates were pretreated with dithiothreitol (Rocha et al. 1988).

Recently, Baric et al. (2004) reported a study on a Croatian boy with an inherited deficiency of SAHH. Molecular analysis of the SAHH gene in this case revealed two different mutations in exon 4: a maternally derived stop codon, and a paternally derived missense mutation. SAHH activity measured in red blood cells was $5-10 \%$ of control values (Baric et al. 2004). Figure 1c, lane 3, shows the boy's red cell SAHH phenotype, designated as $0^{*}$, described by Baric et al. (2004). The electrophoretic position corresponds with the position of SAHH phenotype 1, yet the enzymatic activity determined densitometrically and calculated on the basis of the protein concentration revealed only $7.5 \%$ of the enzymatic activity of normal SAHH phenotype 1.The boy's brother (Fig. 1c, lane 4) also shows SAHH phenotype 1 and only $10 \%$ of normal SAHH activity, suggesting that he also has SAHH deficiency. From the electrophoretic result one can state that at least the paternally derived mutation took place in the SAHH 1 allele.

The combination of densitometry and protein concentration also allowed us to detect SAHH 0-alleles in the heterozygous state. Heterozygous individuals with the 0 -allele exhibit only $30-40 \%$ SAHH activity of the corresponding SAHH phenotype. These carriers seem to be phenotypically inconspicuous as they are healthy blood donors. Observed and expected frequencies of heterozygotes for SAHH 0 in this population are calculated to be 1.3 and $1.2 \%$, respectively. The expected incidence for homozygous individuals with SAHH deficiency is roughly 1 in 30,000 .

In summary, our results show that, in a Croatian population, besides the three common alleles-SAHH 1, SAHH 2, and SAHH 3-the silent allele SAHH 0 and the newly identified electromorphic SAHH 4 variant occur with frequencies of 0.6 and $1.5 \%$, respectively.
Acknowledgements The authors wish to thank Renate Riehle for technical assistance. This study was supported by a grant from the Ministry of Science, Education and Sport of the Republic of Croatia (0108016).

\section{References}

Baric I, Fumic K, Glenn B, Cuk M, Schulze A, Finkelstein JD, James SJ, Mejaski-Bosnjak V, Pazanin L, Pogribny IP, Rados M, Sarnavka V, Scukanec-Spoljar M, Allen RH, Stabler S, Uzelac L, Vugrek O, Wagner C, Zeisel S, Mudd SH (2004) SAdenosylhomocysteine hydrolase deficiency in a human: a genetic disorder of methionine metabolism. Proc Natl Acad Sci USA 101:4234-4239

Bissbort S, Bender K, Wienker TF, Grzeschik KH (1983) Genetics of human S-adenosylhomocysteine hydrolase. A new polymorphism in man. Hum Genet 65:68-71

Bradford MM (1976) A rapid and sensitive method for the quantitation of microgram quantities of protein utilizing the principle of protein-dye binding. Anal Biochem 72:248-254

Cantoni GL, Chiang PK (1980) The role of S-adenosylhomocysteine and S-adenosylhomocysteine hydrolase in the control of biological methylation. In: Cavallini D, Gaull GE, Zaooia V (eds) Natural sulfur compounds: novel biochemical and structural aspects. Plenum Press, New York, pp 67-80

Clarke S, Banfield K (2001) S-Adenosylmethionine-dependent methyltransferases. In: Carmel R, Jacobsen DW (eds) Homocysteine and health disease. Cambridge University Press, Cambridge, pp 63-78

Corbo RM, Palmarino R, Schiattarella E, Giannini MA, Scacchi R (1987) Polymorphism of S-adenosylhomocysteine hydrolase in Italy. Hum Hered 37:186-189

De la Haba G, Cantoni GL (1959) The enzymatic synthesis of S-adenosyl-L-homocysteine from adenosine and homocysteine. J Biol Chem 234:603-608

Hermes M, Osswald H, Mattar J, Kloor D (2004) Influence of an altered methylation potential on mRNA methylation and gene expression. Exp Cell Res 294:325-334

Katsunori A, Nakamura S, Abe K (1984) Gene frequencies of Sadenosylhomocysteine hydrolase (SAHH) in a Japanese population. Hum Genet 68:191-192

Miller MW, Duhl DM, Winkes BM, Arredondo-Vega F, Saxon PJ, Wolff GL, Epstein CJ, Hershfield MS, Barsh GS (1994) The mouse lethal nonagouthi $(\mathrm{a}(\mathrm{x}))$ mutation deletes the S-adenosylhomocysteine hydrolase (Ahcy) gene. EMBO J 13:1806-1816

Raymond M, Rousset F (1995) GENEPOP (version 1.2): a population genetics software for exact tests and ecumenicism. J Hered 86:248-249

Rocha J, Amorim A, Kömpf J, Ritter H (1988) Demonstration of S-adenosylhomocysteine hydrolase polymorphism (E.C.3.3.1.1) by means of isoelectric focusing. Ärztl Lab 34:283-284 
Scheil HG, Borner E (1985) S-Adenosylhomocystein-Hydrolase (EC 3.3.1.1)-Phänotypen und Genfrequenzen in einer westdeutschen Population. Arztl Lab 31:157-158

Scozzari R, Sellitto D, Tassone F, Cerroni L, Aliquo MC (1987) Family and population studies of SAHH and ADA polymorphisms. A possible pitfall in the ascertainment of SAHH electrophoretic phenotypes. Ann Hum Genet 51:295-302
Ueland PM (1982) Pharmacological and biochemical aspects of S-adenosylhomocysteine and S-adenosylhomocysteine hydrolase. Pharmacol Rev 34:223-253 